\title{
Pengaruh Situasi Sosial Dan Nilai Budaya Madura Terhadap Regulasi Emosi Individunya
}

\author{
Setyaningsih $^{1}$ \\ ${ }^{1}$ Program Studi Psikologi, Universitas Trunojoyo Madura \\ ${ }^{1}$ setyaningsih@trunojoyo.ac.id
}

\begin{abstract}
Individual of Madurese ethnic are known temperamental and emotional as well as highly carry self esteem. Social situation and the Madurese cultural values take role in emotion regulation. This research is intended to see and to test of the influence of Madurese social situation and cultural values toward their emotion regulation. This research uses 400 persons as samples taken from 4 (four) regencies available in Madura island by applying Multi stage sampling technique. The data are taken by using the emotion regulation scale, social situation scale and the Madurese cultural value scale. All of these samples are analysed by using the Partial Least Square (PLS) Methode. Output of calculation indicates Madurese cultural values greater impact on emotion regulation compared with social situation.
\end{abstract}

Key word : social situation, Madurese cultural values, emotion regulation.

\begin{abstract}
Abstrak
Selama ini individu etnis Madura diketahui temperamental dan emosional serta menjunjung tinggi harga diri. Situasi sosial dan nilai budaya Madura berperan terhadap regulasi emosi. Penelitian ini bertujuan untuk melihat dan menguji pengaruh dari situasi social dan nilai budaya Madura terhadap regulasi emosi individunya. Penelitian ini menggunakan sampel 400 orang dari empat kabupaten yang ada di Pulau Madura, dengan teknik multistage sampling. Data digali menggunakan skala regulasi emosi, situasi social, skala nilai budaya Madura dan dianalisis dengan menggunakan Partial Least Square (PLS). Hasil perhitungan menunjukkan nilai budaya Madura lebih besar pengaruhnya terhadap regulasi emosi dibandingkan dengan situasi sosial. Untuk penelitian lanjutan bisa dikaitkan dengan faktor trait dari individu.
\end{abstract}

Kata kunci : situasi sosial, nilai budaya Madura, regulasi emosi. 


\section{Pendahuluan}

Menurut Warnaen (2002), di Indonesia etnis Madura adalah etnis terbesar ke tiga . Menurut Spaeth (2000), etnis Madura adalah etnis pengembara terbesar di Indonesia. Orang Madura sering dipandang orang sebagai keras, emosional dan temperamental. Orang Madura disebut sebagai oreng carok oleh orang diluar etnis Madura karena menganggap ciri khas Madura adalah carok (De Jong,1993 ; Smith, 1997). Oleh karena itu, banyak stereotip berkaitan dengan orang Madura. Stereotip ini, tidak selamanya mencerminkan realitas yang sebenarnya, tetapi banyak disebutkan bahwa orang Madura cepat tersinggung, cepat curiga kepada orang lain, memiliki temperamen tinggi atau mudah marah, menaruh dendam pada orang lain dan suka ber tindak kekerasan (De Jongge, 1995 ; Touwen-Bouwsma, 1989).

Gambaran tersebut diatas seolah-olah menunjukan bahwa masyarakat etnis Madura merupakan masyarakat yang penuh dengan kekerasan. Setiap permasalahan seakan selalu berakhir dengan kekerasan (carok). Kesan demikian semakin menambah konotasi negatif terhadap masyarakat etnis Madura, seolah masyarakat etnis Madura tidak pernah bisa diajak kompromi, sehingga susah diatur dan selalu mau menang sendiri, tidak mau tahu keberadaan orang lain.

Seseorang atau individu akan bahagia jika individu tersebut mampu kendalikan emosinya (Garison dalam Mapiare, 2003). Saat inividu melakukan proses kendali emosi maka disebut sebagai proses regulasi emosi. Menurut Richard (Gross, 2007), regulasi emosi adalah saat seseorang mampu menyadari dan mengelola pemikiran serta perilakunya dalam emosi-emosi berbeda. Hal ini sejalan dengan pendapat Fridja, yaitu regulasi emosi adalah cara individu untuk menentukan emosi apa yang dirasakan, saat atau waktu emosi tersebut dirasakan dan bagaimana mengekspresikan dan mengenali emosi tersebut (Fridja, 1986).

Regulasi emosi dianggap penting untuk menentukan keberhasilan seseorang agar dapat berfungsi dengan normal di kehidupannya layaknya pada proses adaptasi, sehingga mampu berespon sesuai dan fleksibel (Thompson dalam Garnefski, dkk., 2001). Kitayama \& Markus, 1995 (dalam Shiraev \& Levy, 2012), menyebutkan emosi adalah produk kultural dan sosial, faktor norma kultural dan lingkungan akan mengatur cara orang mengekspresikan emosinya. Perbedaan 
dalam pengenalan emosi muncul mungkin karena beberapa ekspresi emosi ditanamkan pada diri anak semasa proses sosialisasi dan sebagian tidak (Levy \& Shiraev, 2012). Lebih lanjut dikatakan bahwa bagaimana kita merasakan dan mengekspresikan perasaan itu didasarkan pada personalitas, pengalaman, situasi sekitar, kehadiran atau ketidakhadiran orang lain dan banyak faktor lain. Situasi yang sama dapat diinterpretasikan secara berbeda di berbagai kultur yang berbeda karenanya menimbulkan emosi yang berbeda.

Keunikan etnografis masyarakat etnis Madura yang merupakan nilai budaya Madura nampak pada perilaku dalam menjalin persaudaraan. Hal itu tercermin pada adanya budaya oreng daddhi taretan, taretan daddhi oreng (orang lain menjadi saudara, saudara bisa menjadi orang lain). Secara konkrit, nilai budaya ini bermakna bahwa kesesuaian dalam menjalin persaudaraan atau persahabatan dapat dikukuhkan faktual dan berlangsung lama. Maksudnya, orang lain bisa dianggap sebagai saudara kandung bila memiliki perilaku sejalan atau sesuai watak dasar individu etnis Madura (pseudo kinship). Sebaliknya, meskipun saudara kandung tetapi bila mengalami ketidaksesuaian atau tidak sejalan dalam pendapat atau pandangan serta pendirian maka akan dianggap atau diperlakukan sebagai orang lain (Astro, 2006).

Masyarakat etnis Madura juga mengenal istilah taretan dhibbi' (saudara sendiri), yang menggambarkan perilaku yang sangat humanis. Taretan dhibbi' merupakan perilaku bersahabat dan cenderung berkerabat. Arti konsep tersebut seseorang atau sekelompok orang telah diakui kedekatannya oleh individu atau kelompok masyarakat Madura, seperti kerabat atau saudara sendiri, sehingga tidak ada lagi jarak diantara mereka (Wiyata, 2013). Masyarakat etnis Madura dalam berinteraksi dengan sesama etnis Madura ataupun juga dengan etnis lain telah mengimplementasikan nilai budaya taretan dhibbi' . Dengan syarat bila pada saat menjalin hubungan atau berinteraksi sama-sama dapat saling membantu, saling menghormati, saling menghargai dan akrab maka hubungan itu dapat menjadi taretan dhibbi', sebaliknya bila dalam proses berinteraksi salah satu pihak tidak dapat saling memahami, tidak mau membantu bila mengalami kesulitan, tidak 
saling menghormati atau tidak akrab maka hubungan akan terputus atau bahkan muncul konflik dan kekerasan (Setyaningsih, 2015).

Lebih lanjut menurut Setyaningsih (2015), ciri-ciri taretan dhibbi' adalah peduli pada sesama, saling membantu, dekat seperti keluarga sendiri, akrab, rela berkorban, menghargai dan menghormati orang lain. Untuk menjaga agar hubungan sebagai saudara sendiri (taretan dhibbi') dapat tetap terjaga individu akan melakukan silaturahmi atau bersilaturahmi (mengikat tali persaudaraan atau persahabatan dengan cara saling mengunjungi), membantu disaat orang lain kesusahan, membantu saat orang lain mengalami kesulitan, memberi tahu anak dan keturunan tentang nilai taretan dhibbi', saling menjaga perasaan atau emosi baik terhadap orang lain maupun diri sendiri agar tidak terjadi pertengkaran atau konflik.

Kondisi diatas merupakan bentuk dari situasi sosial. Situasi sosial adalah setiap situasi yang terdapat saling hubungan antara manusia yang satu dengan yang lain (Sherif dalam Gunarsa, 2012). Menurut Myers (2012), bahwa situasi sosial memang sangat memengaruhi individu. Tetapi individu juga memengaruhi situasi sosial. Kedua hal tersebut saling berinteraksi. Menurut Sears (2012), dimana terdapat interaksi sosial maka dapat disebut sebagai situasi sosial.

Masyarakat Madura dalam kehidupannya menggunakan landasan yang penting dan ditaatinya tangga kuasa $b h u, p a^{\prime}$, babbhu', ghuru, rato (ibu, bapak, sesepuh, guru baik formal maupun informal yaitu kyai, dan pemerintah atau raja jaman dulu). Mencermati struktur sosial tersebut bermakna selain harus patuh dan hormat ibu, bapak, orang Madura juga patuh pada tokoh panutan (kyai atau guru) dan pemerintah. Ketundukan masyarakat etnis Madura terhadap struktur social tersebut merupakan standard dalam dinamika kehidupan sosial, budaya dan politik (Rifai, 2007).

Harga diri bagi orang Madura bermakna sosiokultural yang memiliki kaitan dengan posisi seseorang dalam tingkatan sosial. Letak sosiokultural ini menentukan status dan peran individu etnis Madura dalam kehidupan bermasyarakat. Oleh sebab itu, harga diri yang dilecehkan akan diartikan sebagai penghinaan pada kapasitas diri. Bila hal ini terjadi, individu etnis Madura akan merasa seperti manusia yang tak berarti (tada' ajina), pada gilirannya gilirannya 
muncul perasaan malo' (malu), baik pada dirinya sendiri maupun lingkungan social budaya mereka. Malo' (malu) timbul akibat perlakuan orang lain yang tidak mengakui atau mengingkari kapasitas individu. Orang Madura yang sangat menjunjung harga diri dan pemberani akan memilih daripada hidup menanggung malu maka lebih baik mati berkalang tanah (Rifai, 2007; Wiyata, 2013). Dari sikap tersebut diatas muncul ungkapan ango'an poteya tolang, etembhang poteya mata (kematian lebih dikehendaki daripada harus hidup dengan menanggung malu) (Atmosoedirdjo, 1952 dalam Rifai, 2007). Dari uraian diatas akan akan tercipta kondisi psikokultural maupun ekspresi reaktif secara spontan, hal ini terjadi pada level individu dan kelompok (keluarga, kampung, desa atau kesukuan).

Fungsi nilai dalam kehidupan manusia menurut Adisubroto (2000) adalah, untuk rencana umum (general plan) dalam penyelesaian konflik dan pengambilan keputusan ; sebagai standar, yang menunjukkan tingkah laku dari berbagai cara yaitu membawa individu untuk mengambil posisi khusus dalam masalah sosial, berpengaruh terhadap seseorang menentukan ideologi politik dan agama, menunjukkan gambaran-gambaran diri (self) terhadap orang lain, menilai dan menentukan kebenaran dan kesalahan atas diri sendiri atau orang lain, merupakan pusat pengkajian tentang proses-proses perbandingan untuk menentukan individu bermoral atau kompeten, memengaruhi orang lain atau mengubahnya, sebagai standar dalam proses rasionalisasi, yang dapat terjadi pada setiap tindakan yang kurang dapat diterima oleh pribadi atau masyarakat dan meningkatkan self-esteem ; berfungsi motivasional ; berfungsi penyesuaian ; pertahanan ego ; sebagai pengetahuan; sebagai aktualisasi diri.

Fenomena bahwa di dalam individu etnis Madura yang dikenal temperamental dan emosional karena situasi sosial dan nilai budaya Madura yang dianutnya. Seperti pendapat Kitayama \& Markus, 1995 (dalam Shiraev \& Levy, 2012), emosi adalah produk kultural dan sosial, faktor norma kultural dan lingkungan akan mengatur cara orang mengekspresikan emosinya. Maka yang dapat dirumuskan adalah apakah ada pengaruh situasi sosial dan nilai budaya Madura terhadap regulasi emosi individunya. 
Menurut Garrison (dalam Mapiare, 2003), seseorang atau individu atau mereka yang dapat dan mampu kendalikan emosinya akan merasa bahagia. Lebih lanjut dikatakan agar orang bahagia dalam kehidupannya bukan karena dalam dirinya tidak memiliki bentuk-bentuk emosi tetapi kebiasaanya mengerti dan mengendalikan emosi. Proses pengendalian ini juga disebut sebagai proses regulasi emosi.

Menurut Richard (dalam Gross, 2007), regulasi emosi adalah saat seseorang mampu menyadari serta mengelola pemikiran dan perilakunya dalam emosi-emosi berbeda. Hal ini sejalan dengan pendapat Fridja (1986), yaitu regulasi emosi adalah cara individu untuk menentukan emosi apa yang dirasakan, saat atau waktu emosi tersebut dirasakan dan bagaimana mengekspresikan dan mengenali emosi tersebut.

Regulasi emosi dianggap penting untuk menentukan keberhasilan seseorang agar dapat berfungsi dengan normal di kehidupannya layaknya pada proses adaptasi, sehingga mampu berespon sesuai dan fleksibel (Thompson dalam Garnefski, dkk., 2001). Gross (2007), menyatakan bahwa makna regulasi emosi selama ini adalah suatu yang meragukan, apakah berbagai aspek seperti pemikiran, perilaku atau fisiologis yang diubah oleh emosi (regulation by emotion) atau emosi itu sendiri yang diregulasi (regulation of emotion). Nampaknya Gross cenderung setuju pada makna kedua yaitu emosi itu sendiri yang diregulasi mengingat fungsi utama atau primer emosi, adalah mengordinir system respon.

Tujuan dari regulasi emosi individu sering sulit dikenali, tetapi yang dapat disimpulkan bahwa regulasi emosi terkait dengan mengurangi dan menaikkan emosi negatif serta emosi positif (Gross, 2007). Kedua emosi ini, baik emosi negatif dan positif akan timbul saat individu yang memiliki tujuan berinteraksi dengan lingkungannnya dan orang lain. Bila individu dapat mencapai tujuannya maka yang akan timbul adalah emosi positif dan bila individu mendapatkan halangan untuk mencapai tujuannya maka yang akan timbul adalah emosi negatif. Bentuk emosi positif misalnya senang serta gembira, dan bentuk emosi negatif misalnya marah, sedih dan takut.

Lebih lanjut dikatakan Gross (2007), keadaan seseorang dapat berpengaruh terhadap tujuan regulasi emosi orang tersebut. Sehingga sifatnya sangat spesifik. 
Misalnya, seseorang dapat saja meningkatkan marahnya dengan sengaja agar orang lain merasa takut. Dengan tujuan supaya orang yang meningkatkan marahnya, ketakutannya tidak dimanfaatkan orang lain.

Ciri-ciri individu yang memiliki kemampuan regulasi emosi menurut Goleman (2004), 1. Kendali diri, dalam arti mampu mengelola emosi dan impuls yang merusak dengan efektif ; 2. Memiliki hubungan interpersonal yang baik dengan orang lain ; 3. Memiliki sikap hati-hati ; 4. Memiliki adaptibilitas, yang artinya luwes dalam menangani perubahan dan tantangan ; 5. Toleransi yang lebih tinggi terhadap frustrasi ; 6. Memiliki pandangan yang positif terhadap diri dan lingkungannya.

Menurut Sherif (dalam Gunarsa, 2012), situasi sosial adalah setiap situasi yang terdapat saling hubungan antara manusia yang satu dengan yang lain. Menurut Myers (2012), bahwa situasi sosial memang sangat memengaruhi individu. Tetapi individu juga memengaruhi situasi sosial. Kedua hal tersebut saling berinteraksi.

Menurut Sears (2012), situasi sosial adalah setiap situasi yang terdapat saling hubungan antara manusia yang satu dengan manusia yang lain. Sehingga dapat dikatakan bila terdapat interaksi sosial maka dapat dikatakan situasi sosial.

Proses interaksi situasi sosial terhadap individu interaksi terjadi dalam tiga cara (Snyder \& Ickes, 1985 dalam Myers, 2012) : a. situasi sosial tertentu seringkali berpengaruh terhadap orang yang berbeda dengan cara yang berbeda ; b. orang seringkali memilih situasinya (Ickes, 1997) ; c. orang seringkali menciptakan situasi.

Beberapa hal yang mempengaruhi interaksi sosial menurut Sargent (Santoso, 2010: 199) adalah : 1. Hakekat situasi social (the nature of social situation) ; 2. Kekuasaan norma-norma yang diberikan oleh kelompok social (the norms prevailing in any given social group) ; 3. Kecenderungan kepribadian sendiri (the own personality trend) ; 4. Kecenderungan sementara individu (a person's transitory tendences) ; 5. Proses menanggapi dan menafsirkan suatu situasi (the process of perceiving and interpretating situation).

Dalam berinteraksi individu etnis Madura melihat suatu situasi yang terjadi (Setyaningsih, 2015). Situasi yang dapat melancarkan interaksi yaitu : 1. Saling 
membantu bila ada yang mengalami kesulitan; 2. Saling menghormati ; 3. Saling menghargai ; 4. Hubungan bersifat akrab. Sebaliknya, bila situasinya tidak saling membantu bila ada yang mengalami kesulitan, tidak saling menghormati, tidak saling menghargai dan tidak akrab maka interaksi dapat menimbulkan konflik bahkan interaksi dapat terputus.

Hubungan pertemanan dalam masyarakat Madura seringkali didasari oleh semangat timbal balik. Sehingga apabila hubungan atau pertemanan dijalin dengan baik dan senantiasa menjadi semangat, referensi dan landasan dalam kehidupan social orang Madura, akan tercipta kehidupan penuh kedamaian, teduh, sejuk serta nyaman. Kondisi ini timbul bila konflik dapat diantisipasi serta dicegah lebih awal.

Hal ini juga sesuai dengan penelitian dari Sudagung (2001), bahwa para migran Madura di Kalimantan Barat memunyai pandangan yang baik terhadap Bugis, yang sama-sama bermigrasi kesana. Pandangan tersebut disebabkan oleh kesamaan agama Islam yang dianut orang Bugis, dan juga karena mereka bisa diajak bekerja sama oleh orang Madura. Kontak dan hubungan yang kontraktual yang bersifat mutualis atau saling menguntungkan antara majikan dan pekerjanya. Hasil penelitian Sudagung (Cahyono, 1997), sifat ethnosentrisme orang Madura dapat membangkitkan hasrat untuk saling membantu dalam bekerja secara keras yang didukung oleh pembawaannya yang ulet dan tahan banting.

Menurut Allport (dalam Adisubroto, 2000), nilai adalah suatu keyakinan yang mendasari seseorang untuk bertindak berdasarkan pilihannya. Kluckhon, 1951 (dalam Berry, 1999) menyatakan bahwa nilai adalah suatu konsep yang dianut individua atau anggota kelompok secara kolektif mengenai sesuatu yang diharapkan (desirable) dan berpengaruh terhadap pemilihan cara maupun tujuan tindakan dari beberapa alternatif.

Nilai adalah sesuatu yang diyakini kebenarannya serta mendorong orang untuk mewujudkannya. Penerimaan nilai oleh manusia dilakukan secara kreatif dan aktif. Proses individu menerima nilai ini terjadi hubungan dialektis antara roh objektif dengan roh subjektif. Artinya, roh objektif akan berkembang jika didukung oleh roh subjektif, sebaliknya roh subjektif akan berkembang dengan berpedoman 
kepada roh-roh objektif yang diposisikan sebagai cita-cita yang harus dicapai. (Berry, 1999).

Masyarakat Madura dalam kehidupannya menggunakan landasan yang penting dan ditaatinya tangga kuasa bhu, pa', babbhu', ghuru, rato (ibu, bapak, sesepuh, guru baik formal maupun informal yaitu kyai, dan pemerintah atau raja jaman dulu). Mencermati struktur social tersebut tergambar bahwa disamping harus patuh pada ibu, bapak, orang Madura diharapkan juga tunduk pada tokoh panutan dan pemerintah. Ketundukan masyarakat etnis Madura terhadap struktur social tersebut merupakan penentu dalam dinamika kehidupan social, budaya dan politik (Rifai, 2007).

Harga diri bagi orang Madura bermakna sosiokultural yang memiliki kaitan dengan posisi seseorang dalam tingkatan social. Letak sosiokultural ini menentukan status dan peran individu etnis Madura dalam kehidupan bermasyarakat. Oleh sebab itu, harga diri yang dilecehkan akan diartikan sebagai penghinaan pada kapasitas diri. Bila hal ini terjadi, individu etnis Madura akan merasa seperti manusia yang tak berarti (tada' ajina). Sehingga gilirannya muncul perasaan malo' (malu), baik pada dirinya sendiri maupun lingkungan social budaya mereka. Malo' (malu) timbul akibat perlakuan orang lain yang tidak mengakui atau mengingkari kapasitas individu. Orang Madura yang sangat menjunjung harga diri dan pemberani akan memilih lebih baik mati berkalang tanah daripada hidup menanggung malu (Rifai, 2007 ; Wiyata, 2013). Dari sikap tersebut diatas muncul ungkapan ango'an poteya tolang, etembhang poteya mata (kematian lebih dikehendaki daripada harus hidup dengan menanggung malu) (Atmosoedirdjo, 1952 dalam Rifai, 2007). Sehingga tercipta kondisi psikokultural maupun ekspresi reaktif secara spontan, hal ini terjadi pada level individu dan kelompok (keluarga, kampung, desa atau kesukuan). 


\section{Metode Penelitian}

Penelitian ini menggunakan pendekatan kuantitatif. Populasi subjek masyarakat etnis Madura di empat kabupaten di Madura (Kabupaten Bangkalan, Kabupaten Sampang, Kabupaten Pamekasan dan Kabupaten Sumenep). Mengambil subyek di pulau Madura dengan asumsi bahwa subyek yang diteliti adalah etnis Madura dengan nilai budayanya sehingga subyek akan lebih banyak menginternalisasi nilai budaya Madura bila dibandingkan dengan subyek yang tinggal di luar pulau Madura. Jumlah sampel 400 orang yang dibagi menjadi seratus orang tiap kabupaten. Masing-masing lima puluh laki-laki dan limapuluh perempuan. Usia 17 - 70 tahun. Dengan pertimbangan usia 17 tahun seseorang sudah menginternalisasi nilai dan norma yang ada. Sampai dengan 70 tahun dengan pertimbangan seseorang masih dapat mengingat dan menjawab apa yang pernah dialami dan dirasakan. Usia diatas 70 tahun ada kecenderungan mengalami degeneratif. Teknik sampling yang digunakan cluster sampling, multi stage. Kabupaten Bangkalan di dapatkan di Kelurahan Kramat Kecamatan Bangkalan, Kabupaten Sampang di Kelurahan Kamoning Kecamatan Sampang, Kabupaten Pamekasan di kelurahan Panaguan Kecamatan Larangan dan Kabupaten Sumenep di Kelurahan Dungkek Kecamatan Dungkek.

Skala yang digunakan yaitu Skala Regulasi Emosi, Skala Situasi Sosial dan Skala Nilai Budaya Madura. Teknik pengumpulan data dengan kuesioner menggunakan skala Likert dengan empat pilihan jawaban, Sangat Setuju (SS), Setuju (S), Tidak Setuju (TS), Sangat Tidak Setuju (STS).

Metode analisis data yang digunakan untuk mengetahui pengaruh antar variable adalah dengan menggunakan Partial least Square (PLS). PLS adalah suatu metode yang berbasis kelompok regresi. PLS memiliki asumsi data penelitian bebas distribusi (distribution free), artinya data penelitian tidak mengacu pada salah satu distribusi tertentu. 


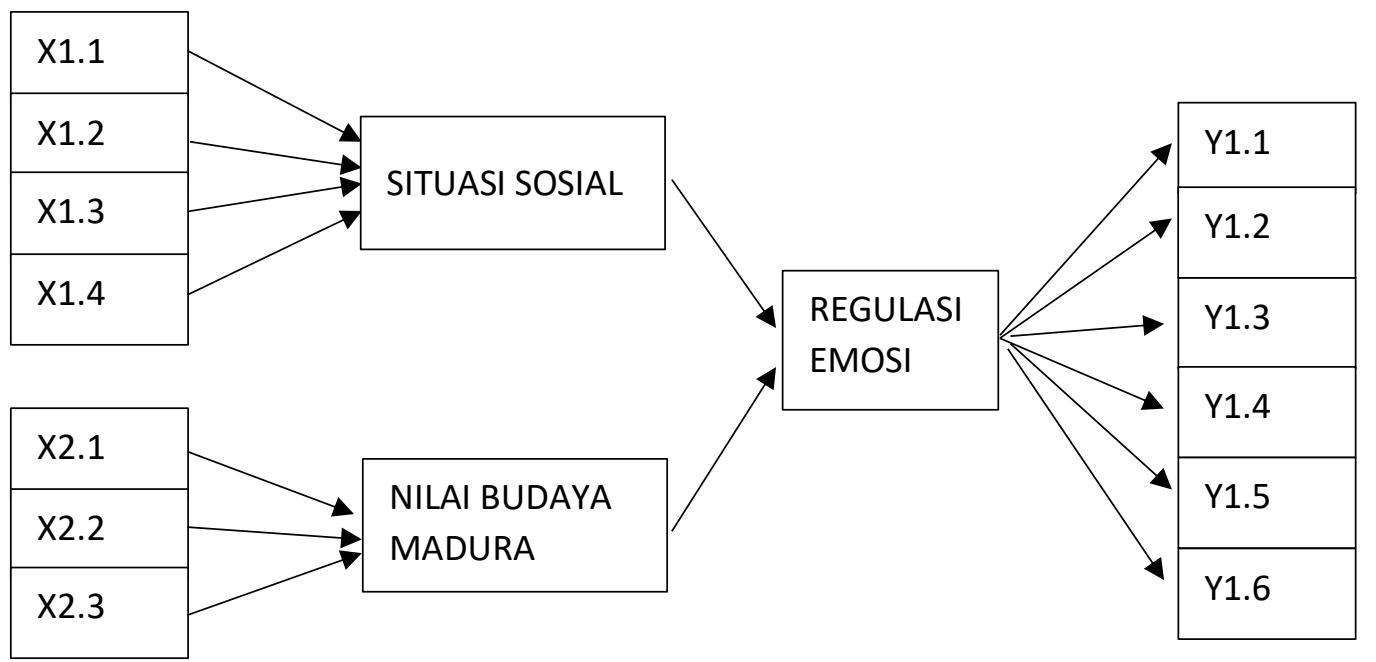

\section{Gambar 1}

\section{Rancangan Analisis}

\section{Hasil dan Pembahasan}

Hasil pengujian outer model menghasilkan loading factor yang cukup valid yaitu diatas 0,5. Untuk memeroleh Goodness of Fit yang optimal, maka dilakukan pengujian dengan menghilangkan salah satu indikator yang loading factornya kecil (dibawah 0,6), yaitu konstruk 1. Situasi Sosial : saling menghormati ;2. Konstruk Regulasi Emosi : hubungan interpersonal yang baik, sikap hati-hati, toleransi tinggi terhadap frustrasi.

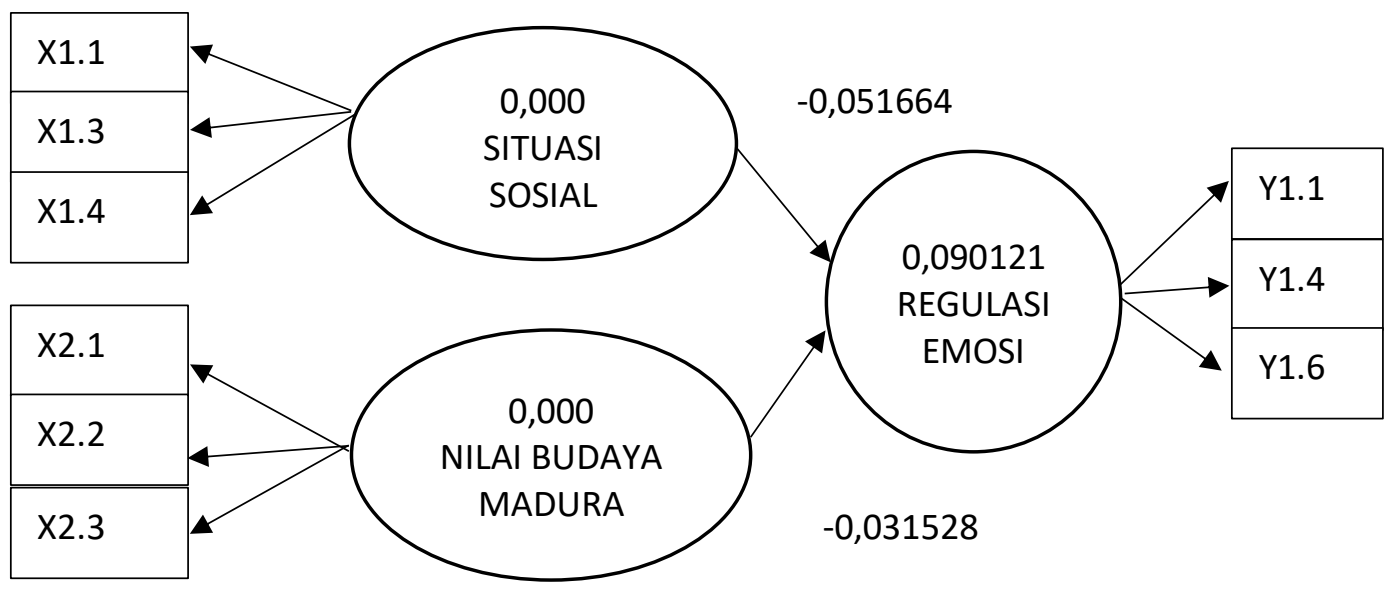

Gambar 2

Hasil Analisis Model PLS 
Untuk melihat hubungan antar konstruk atau variabel maka dilakukan pengujian inner model yang akan memperlihatkan signifikansi setiap path coefficient antar konstruk. Hasil analisis sebagai berikut :

Tabel 1

\begin{tabular}{|l|l|l|l|l|}
\hline No & Variabel & Path Coefficent & T Statistics & R Square \\
\hline 1. & $\begin{array}{l}\text { Situasi Sosial } \rightarrow \text { Regulasi } \\
\text { Emosi }\end{array}$ & $-0,051664$ & 0,316206 & \multirow{2}{*}{0.090121} \\
\hline 2. & $\begin{array}{l}\text { Nilai Budaya } \\
\text { Madura } \rightarrow \text { Regulasi Emosi }\end{array}$ & 0,31528 & 2,759576 & \\
\hline
\end{tabular}

Nilai T- Statistik untuk hubungan nilai budaya Madura ke regulasi emosi $(2.759576)>t(1-\alpha ; n-1)(1.65)$ dan bertanda positif. Dpat dikatakan bahwa nilai budaya Madura memiliki pengaruh yang signifikan terhadap regulasi emosi. Hal ini menunjukkan bahwa variabel nilai budaya Madura berpengaruh positif dan signifikan terhadap regulasi emosi. Semakin tinggi nilai budaya Madura maka semakin tinggi regulasi emosi.

Kondisi sosial berpengaruh negatif dan tidak signifikan terhadap regulasi emosi. Hal ini menunjukkan bahwa variabel situasi sosial tidak cukup kuat memengaruhi regulasi emosi. Semakin tinggi situasi sosial semakin rendah regulasi emosi, begitu juga sebaliknya.

Dari table juga terlihat pengaruh beberapa variabel eksogen terhadap variable endogen. Situasi sosial, nilai budaya Madura secara simultan memengaruhi regulasi emosi sebesar $0.090121(9.0121 \%)$, sedangkan sisanya $90.49879 \%$ dipengaruhi oleh konstruk lain yang tidak dimasukkan ke dalam model penelitian. Hal ini menunjukkan bahwa situasi sosial bersama-sama nilai budaya Madura berkontribusi sebesar $9.0121 \%$ terhadap regulasi emosi. Nilai budaya Madura lebih besar pengaruhnya terhadap regulasi emosi.

Situasi sosial dan nilai budaya Madura secara simultan memengaruhi regulasi emosi. Semakin tinggi situasi sosial dan semakin menginternalisasi nilai budaya Madura semakin tinggi regulasi emosi. Sebaliknya, semakin rendah situasi sosial dan tidak menginternalisasi nilai budaya Madura maka semakin rendah 
regulasi emosi. Hal ini tidak berlaku secara terpisah pengaruh situasi sosial terhadap regulasi emosi. Semakin tinggi situasi sosial maka semakin rendah regulasi emosi, sebaliknya semakin rendah situasi sosial maka semakin tinggi regulasi emosi. Nilai budaya Madura lebih besar pengaruhnya terhadap regulasi emosi.

Individu menciptakan situasi saling membantu, saling menghargai serta menjalin hubungan yang bersifat akrab bersama-sama dengan internalisasi dan menjalankan $b u^{\prime}, p a^{\prime}$, babbhu, ghuru, ratoh (hormat dan patuh pada ibu, bapak, sesepuh, guru, pemerintah), malo' (malu karena hilangnya martabat atau harga diri), taretan daddhi oreng, oreng daddhi taretan (saudara menjadi orang lain, orang lain menjadi saudara) maka akan memengaruhi regulasi emosi individu etnis Madura. Regulasi emosi individu etnis Madura akan meningkat bila individu menginternalisasi dan menjalankan nilai budaya Madura $b u^{\prime}, p a^{\prime}$, , babbhu, ghuru, ratoh (hormat dan patuh pada ibu, bapak, sesepuh, guru, pemerintah), malo' (malu karena hilangnya martabat atau harga diri), taretan daddhi oreng, oreng daddhi taretan (saudara menjadi orang lain, orang lain menjadi saudara) dan tidak menciptakan saling membantu, saling menghargai serta tidak menjalin hubungan yang bersifat akrab. Sebaliknya bila individu menciptakan situasi saling membantu, saling menghargai serta menjalin hubungan yang bersifat akrab bersama-sama dengan individu tidak menginternalisasi dan menjalankan $b u^{\prime}, p a^{\prime}$, , babbhu, ghuru, ratoh (hormat dan patuh pada ibu, bapak, sesepuh, guru, pemerintah), malo' (malu karena hilangnya martabat atau harga diri), taretan daddhi oreng, oreng daddhi taretan (saudara menjadi orang lain, orang lain menjadi saudara) maka regulasi emosi individu etnis Madura akan menurun.

Hal ini dapat dipahami bahwa semakin individu berada pada suatu situasi yang tidak nyaman maupun tidak kondusif maka individu akan berupaya untuk melakukan suatu usaha agar individu merasa nyaman. Hal ini sesuai dengan pendapat Gross (2007), bahwa regulasi emosi berkaitan dengan mengurangi dan menaikan emosi negatif serta emosi positif. Kedua emosi ini, baik emosi negatif dan emosi positif ini timbul saat individu yang memiliki tujuan berinteraksi dengan lingkungannya dan orang lain. Bila individu dapat mencapai tujuannya 
maka akan timbul emosi positif. dan bila individu mendapatkan halangan untuk mencapai tujuannya maka yang akan timbul adalah emosi negatif.

Hal ini juga berkaitan dengan fungsi dari regulasi emosi, yaitu: pilihan respon adaptif yang bervariasi secara signifikan pada situasi yang berbeda, mengevaluasi lebih luas perbedaan individu dalam kapasitas emosi, menanggapi emosi secara fleksibel, merespon sesuai dengan situasi, meningkatkan performance, mempertinggi emosi positif, mengurangi emosi negatif. (Thompson, 1994 ; Gross, 2007).

Emosi adalah bentuk kultural dan sosial, faktor norma kultural dan lingkungan akan mengatur cara orang mengekspresikan emosinya (Kitayama \& Markus, 1995 dalam Levy \& Shiraev, 2012). Perbedaan dalam pengenalan emosi muncul mungkin karena beberapa ekspresi emosi ditanamkan pada diri anak semasa proses sosialisasi dan sebagian tidak (Levy \& Shiraev, 2012). Lebih lanjut dikatakan bahwa bagaimana kita merasakan dan mengekspresikan perasaan itu didasarkan pada personalitas, pengalaman, situasi sekitar, kehadiran atau ketidakhadiran orang lain dan banyak faktor lain. Situasi yang sama dapat diinterpretasikan secara berbeda di berbagai kultur yang berbeda karenanya menimbulkan emosi yang berbeda.

Penelitian Mesquita (dalam Gross, 2007), bahwa diberbagai budaya proses social dan psikologis dapat bervariasi. Hal ini sesuai dengan cultural models theory. Begitupula dengan regulasi emosi, menurutnya regulasi emosi tidak sekedar berkaitan dengan proses intrapersonal, akan tetapi emosi di regulasi sesuai dengan dimana dan bagaimana cara individu tersebut menjalani kehidupan. Regulasi emosi terjadi pada tataran budaya praktis melalui penstrukturan situasi social dan dinamika interaksi sosial, usaha orang terdekat untuk memodifikasi situasi individu yang bersangkutan, poin perhatian seseorang atau makna yang diambil dalam berbagai situasi, dan kesempatan yang tersedia dalam perilaku emosional dalam hal ini regulasi emosi. Kemudian dalam tataran kecenderungan psikologis individu menunjukkan perbedaan budaya melalui orientasi yang berbeda seperti menghindari atau menghadapi suatu situasi tertentu, perspektif umum tentang 
situasi dan makna yang menonjol di dalamnya, dan kecenderungan perilaku yang berkaitan dengan emosi yang ada.

Berdasar hasil analisis bahwa ada kontribusi sebesar $9.0121 \%$ variable situasi social dan nilai budaya Madura terhadap regulasi emosi. Sedangakan sisanya $90.49879 \%$ dipengaruhi variabel lain yang tidak diteliti tetapi diduga memberikan pengaruh terhadap regulasi emosi.

Secara teoritis ada beberapa faktor internal dan eksternal yang memengaruhi regulasi emosi seseorang, yaitu : kognitif (Zelazo dalam Gross \& John, 2004), motivasi (Fischer dalam Philippot, 2004), usia (Gross \& John, 2004), jenis kelamin (McRae, 2008), aspek social terutama pengaruh kelompok. (Thompson, 1994), pengetahuan tentang emosi (Brener \& Salovey dalam Salovey \& Skufter, 1997), religiusitas (Krause dalam Coon, 2005), kepribadian (Cohen \& Armeli dalam Coon, 2005), norma (Fischer dalam Philippot, 2004), perbedaan individual (Gross, 2007).

\section{Kesimpulan dan Saran}

Kondisi sosial dan nilai budaya Madura berpengaruh terhadap regulasi emosi. Nilai budaya Madura berpengaruh lebih kuat terhadap regulasi emosi. Model yang telah terbentuk melalui penelitian ini dinyatakan sebagai model yang memiliki daya prediksi cukup baik, tetapi diperlukan usaha pengembangan model agar diperoleh model yang benar-benar memiliki daya prediksi yang sangat baik. Sebagai perkembangan ilmu khususnya Psikologi Sosial bila mempelajari budaya Madura perlu untuk melihat sejarah dari setiap kabupaten karena latar belakang sejarah berbeda maka berbeda pula budaya dan perilakunya. Melihat pentingnya aspek psikologis pada diri individu maka bila meneliti perilaku etnis Madura juga menyertakan aspek psikologis dari individu, misalnya trait. Untuk subyek penelitian karena situasi sosial dan nilai budaya Madura berpengaruh terhadap regulasi emosi utamanya nilai budaya Madura maka subyek dapat lebih menginternalisasi nilai budaya Madura. Sedangkan untuk pemerintah kabupaten bisa lebih menyosialisasikan nilai budaya Madura terhadap penduduknya. 


\section{Daftar Pustaka}

Adisubroto, D., Hadipranata, A. Walgito, B., Masrun. \& Haditono, S.R. (2000). Peran Psikologi di Indonesia: Kumpulan Pidato Pengukuhan Guru Besar Fakultas Psikologi UGM. Yogyakarta: Yayasan Pembisan Fakultas Psikologi.

Baron, R. A. \& Byrne, D. (2010). Psikologi Sosial. Terjemahan Ratna Djuwita. Edisi ke dua belas. Jakarta: Erlangga.

Berry, J., W,. Portinga, Y. H., Segal, M.H., \& Dasen, P.R. (1999). Psikologi Lintas Budaya. Aplikasi Dan Penelitian. Terjemahan Edi Suhardono. Jakarta: Gramedia.

Berkowitz, L. (1999). Agresi. Terjemahan Hartini Woro S. Jakarta: Pustaka Binaman Pressindo.

De Jonge, Huub, (2013). Garam, Kekerasan, Dan Adua Sapi. Bidik-Phronesis Publishing.

Frijda, N. H. (1986). The Emotion: Studies in Emotion and Social Interaction. Cambridge University Presss.

Garnefski, et all. (2001). Cognitive Emotion Regulation and Emotional Problems. Psychological Healt. Leiden University.

Gerungan, W. A. (2008). Psikologi Sosial. Bandung: PT. Eresco.

Glaser, R.K \& ,Moynihan, J. A. (1981). Accomodating Deversity: National policies that Prevent Ethnis Conflict. Cambridge University Press.

Gross, J.J. \& John,O.P. (2007). Individual Differences in Two Emotion Regulation Processes: Implication for Affect, Relationship and Well Being. Journal of Personality And Social Psychology. Vol.85. No: 2. Pp. 348-362.

Gunarsa, S. (2003). Psikologi Perkembangan Dewasa Muda. Jakarta: Gresindo.

Myers, David. (2011). Social Psychology. $11^{\text {th }}$ edition. New York: Mc Graw Hill.

Rifai, M.A. (2007). Manusia Madura. Pembawaan, Perilaku, Etos Kerja, Penampilan dan Pandangan Hidupnya seperti dicitrakan Peribahasanya. Yogyakarta: Pilar Media.

Sears, O.D., Peplau, L.A., \& Taylor, S.E. (2012). Psikologi Sosial. Terjemahan Tri Wibowo. Edisi ke dua belas. Jakarta: Kencana Prenada Media Group.

Shaw, M. \& Costanzo, P.R. (1995). Theories of Social Psychology. Tokyo: McGraw Hill.

Shiraev, E.B. \& Levy, D.A. (2012). Psikologi Lintas Kultural.

Soemardjan, S. (2001). Konflik Antar Suku di Indonesia. Jakarta: Yayasan IlmuIlmu Sosial. 
Pengaruh Situasi Sosial dan Nilai Budaya Madura...

Sudagung, H.S. (2001). Mengurai Pertikaian Etnis: Migrasi Swakarsa Etnis Madura ke Kalimantan Barat. Jakarta: ISAI.

Thompson, R.A. (1994). Emotion Regulation. A Theme in Search of Definition. Monographs of The Society for Research in Child development. Vol. 59. NO. 23/3. Pp. 25-52.

Warnaen, S. (2002). Stereotip Etnis dalam Masyarakat Multietnis. Yogyakarta: Matabangsa. 